\title{
Structural Conditions for Conflict Mediation in Civil Wars: The Role of Aid and Social Service Provision
}

\section{Rob Kevlihan}

\begin{abstract}
Despite a considerable body of knowledge that examines the negative effects of aid and related social services during civil wars, the role these same services can contribute to conflict management and transformation is less well understood. This article describes findings from a research study undertaken by the author to examine this question through a comparison of experiences with respect to social service provision in three very different conflicts - Northern Ireland, Tajikistan and Sudan. It discusses the ways that aid and social service provision can change structural conditions, making mediation efforts more likely. It also considers the limitations of aid's effectiveness in this regard.
\end{abstract}

\section{Keyword}

Conflict mediation, mediators, civil war, social service provision

\section{Introduction}

No account of civil wars can avoid addressing the so-called "greed versus grievance" debate. This debate came to prominence in the late 1990s, largely as a consequence of "large n" quantitative case studies analyzing possible causes of civil war. Much of this work reflected a preoccupation with the political economy of conflict, considering the impact of the availability of valuable inputs (primarily easily appropriable natural resources, primary commodities or access to an external sponsor), or to use a popular shorthand, greed (Collier 1999), over political programs designed to address particular issues (such as economic, education or other inter group differentials) - otherwise known as grievance. Thus the availability of readily exploitable natural resources such as hardwoods or diamonds facilitates conflicts by acting as the fuel upon which insurgents feed. Some of the qualitative literature on conflict in Africa also tends towards this line of reasoning; in resource poor contexts, competition over appropriable resources defines the manner in which states are formed and the nature of political and social competition (and conflict) within such states (Reno 1998; Bayart 1993). 
In more recent years, however, this 'greed' versus 'grievance' dichotomy has been accepted as less than useful for analytical purposes (Sambanis 2005). The availability or non-availability of easily appropriable resources may define the opportunity structure for rebellion (Davies 2002), without precluding the existence of a 'grievance', or grievances, while grievance type issues have been identified as significant in assessing the likelihood of conflict onset in "large n" studies (Thyne 2006; Urdal 2006; Humphreys 2005). More recent studies have also reaffirmed the importance of ethnic difference particularly the exclusion of large ethnic minorities from power, an issue that the greed literature had largely dismissed (Buhaug et al. 2014; Cedermanet al. 2013). The greed versus grievance literature has also been criticized for failing to consider what actually happens during civil wars (Sislin and Pearson 2006), with the macro comparative approach underlying these studies failing to consider the intensely local nature of many civil conflicts, particularly the dynamics between national level cleavages and local conflict, and the "messiness" of civil wars at the local level (Autesserre 2006; Kalyvas 2006).

Increasingly, the analysis of civil war causes and processes links the availability of resources that define the opportunity structure for financing insurgencies with political grievances, rather than emphasizing one alone. Recent analyses that draw from this perspective emphasize either the salience of opportunity structures defined by the presence or absence of easily appropriable resources (either natural resources such as diamonds, primary commodity exports such as hardwoods or drugs), or alternatively, to the presence or absence of an external patron; both heighten or lower barriers to entry of new insurgences, and the importance of maintaining control over these resources. These factors, it is argued, strongly influence the nature of insurgency relations with local populations (Weinstein 2007; Metelits 2010; Kevlihan 2013). Incentives, in other words, are increasingly recognized as important, regardless of whether one subscribes to (either implicit or explicit) assumptions of insurgents acting at all times as rational actors. The implication for efforts at conflict mediation and resolution / transformation are significant. If resources matter when considering the likelihood of conflict onset and conflict intensity, then by extension, resources should also matter when efforts are made to end conflicts. Opportunity structures may provide incentives for a continuation of violent conflict or potentially in a positive sense, as incentives that can improve the chances of mediation being successful.

\section{Aid and other social services as a resource}

Let us now turn to one particular class of resources often provided during conflicts - resources provided through humanitarian aid or social service systems.

The question of how humanitarian aid has impacted on conflict dynamics is something that has been the focus of considerable discussion over the last 30 years. It is now widely recognized that the provision of humanitarian assistance has political consequences, despite strong rhetorical and operational commitments of some humanitarian agencies with respect to impartiality and neutrality in the provision of this much needed aid (Middleton and O'Keefe 2006; O'Hagan 1999; MacFarlane 2006; Kuperman 2008). Such political consequences arise from providing humanitarian assistance into war zones, where $\underline{\text { such assistance becomes a resource in what are typically resource poor situations (Keen 1994, 1999; De }}$ 
Waal 1988, 1997; Prendergast 1996; DeMars 2000; Anderson 1999).

But what of social services that are not provided by aid organizations or funded by aid donations? There is considerably less research on the impact of such services on conflict dynamics, in part because of the relative scarcity of conflicts in situations where social services provided through nonaid channels have been strong. An important exception to this is with respect to social service provision in Northern Ireland during the conflict there, where the British welfare state continued to function, and indeed in important respects, actually strengthened its capacity to function, over the course of the Troubles. Literature on the impact of the Northern Irish conflict on social services tends to come under the social policy / social planning rubric, often with a particular disciplinary focus depending on the nature of the social service being discussed (i.e. health, education, housing / urban planning, social work practice etc.). This literature addresses the practical difficulties of providing social services in the context of civil violence rather than the potentially broader impacts on the conflict as a whole. Limitations on the ability of the state to provide services were typically overcome by a combination of additional resources (both resources inputs and increased general security) and local adaptation, together with a high degree of tolerance for the continued provision of services by combatants on all sides. During the conflict itself, state social service organizations also distanced themselves from the coercive apparatus of the state, which was itself a belligerent in the conflict, becoming autonomous in their ability to deliver services to all sides. [Author's note: Because of the diversity of these writings I will not attempt to cite all relevant sources in this section. However, for a classic account of the impact of violence on social service provision during Northern Ireland in the 1970s, see Darby and Williamson(1978)].

\section{Aid, social services and conflict mitigation}

Given the long standing recognition that the provision of aid during conflicts can intensify and prolong these conflicts, what policy recommendations have been developed in response? The most popular remedy has been for aid providers to seek to do no harm in the provision of such services, while seeking as far as possible, to build local capacity for peace and peace-building (Anderson 1998). The apparent alternative - of not providing aid during civil wars - is unacceptable to most analysts and commentators (including this author) because of the humanitarian imperative to assist those in need.

Within the literature on Northern Ireland, the focus has primarily been on efforts within social service systems to bring divided communities together - one prominent area has been efforts at promoting integrated education, for example, as a space for children from both Catholic and Protestant backgrounds to be educated together.

[Author's Note: for some of the extensive literature on integrated education in Northern Ireland, see Donnelly et al (2006), O’Connor (2002), Stephen (2005) and Wardlow (2006)].

Other studies have examined work done in the community and voluntary sector more generally to bring communities together (Fitzduff 1995) and the manner in which the health service continued to function and (largely) serve all in need (Smyth et al. 2001; Lyons 1978), as well as adjustments made within the probation service to facilitate social support to prisoners (Chapman 1998) despite initial 
boycotts (von Tangen Page 1998; Hillyard 1978). In contrast, however, within the field of urban planning, extensive work has also been done on how the interaction of housing policies and security concerns have led to increasing levels of segregation, particularly in Belfast (Boal 2000; Murtagh 2002; Shirlow 2000, 2001, 2003; Shirlow and Murtagh 2006; Boal 1981; Doherty and Poole 2000; Kennedy and Birrell 1978). This development, while achieving conflict management goals in reducing levels of violence, may, in the contemporary period, actually have resulted in significant barriers to comprehensive conflict transformation at the local level in so-called interface areas. The use of the term "Peace Lines" to designate the high walls and other barriers built up over the course of the Troubles to separate communities (and indeed in some cases further enhanced in the post conflict period) illustrates this approach - which is very much one of 'negative' (i.e. an absence of violence) as opposed to 'positive' peace.

[Author's note: for a discussion of these terms, see Galtung (1964)].

\section{Aid, social services and structural conditions to mediation}

Given the well-documented potential for aid and social services provided during times of conflict to facilitate increased conflict, and the relatively modest claims made for the potentially conflict dampening effects of aid and social service provision, are we then, as Fiona Terry (2002) argues, condemned to repeat? Research to date has largely implied that we can do no more than try to minimize the negative impacts of aid during conflicts. This answer is unsatisfying, and led me to ask under what circumstances, if any, can aid and other social services contribute to the management and transformation of civil wars.

Based on field research conducted across three quite different case studies - namely Sudan, Tajikistan and Northern Ireland, I argue that aid and social services can contribute to peace indirectly by contributing to changes within insurgent movements. Looking at the impact of social services either provided through aid or as part of systems provided by welfare states, in each case, my research has traced changes that occurred during conflicts in Northern Ireland, Tajikistan and South Sudan. New incentives provided by social services financed by aid or provided directly by governments resulted in changes within insurgent movements in some of the case studies - primarily in Northern Ireland and South Sudan. These changes - including the development of political wings and/or of systems of civil administration that are incentivized through opportunities created by the presence of aid or social service systems-make political settlements easier to attain. Such changes arise because insurgents will always look for ways to garner resources or support for themselves, including ways of maximizing gains from aid or social service systems. However, under certain circumstances these efforts can support or incentivize changes within these same movements. The paragraphs that follow will briefly describe how these dynamics played out in each case.

In the case of Northern Ireland, social service provision contributed to the 1998 peace agreement in two important ways. The first was that the British state succeeded, over time, in addressing core grievances of the minority Catholic community - particularly with respect to housing and discrimination 
in the provision of services. That meant that these kinds of issues no longer had to be addressed in the context of the peace agreement itself. This is evident from the text of the agreement itself. Issues that had been contentious at the outset of the Troubles - such as discrimination in the allocation of public housing, for example - were not referenced in the agreement as they were no longer issues of contention. Addressing such issues was possible in large part because of the level of resources available to the social service system in Northern Ireland throughout the Troubles, together with the ability of social service agencies, such as the Housing Executive, to function across all of Northern Ireland, despite periods of significant difficulty.

The second contribution of social services to peace relates to the changing opportunity structure that the provision of social services in hardcore republican areas of Northern Ireland provided to republican insurgents - particularly to the Provisional Irish Republican Army (IRA) and its related political wing, Sinn Féin. While never the only broker between local populations and the welfare arm of the British state in republican areas (the Catholic Church also exerting considerable influence, especially in education), republican paramilitaries had the capacity to impose themselves as brokers in areas where they maintained a significant presence. In the case of the Provisional IRA and Sinn Féin, it was the political wing of the party that ultimately took on this role. As a consequence, Sinn Féin activists became increasing involved in day-to-day issues of distributional politics in areas where they exercise influence, with its advice centres and its engagement in community activism more generally, allowing Sinn Féin to become important intermediaries between local populations and social service structures. While not the only factor in the electoral success of Sinn Féin and moves towards a peace process in Northern Ireland, it was nonetheless an important one. Bluntly put, the more gains that could be made through such brokerage activities, the greater the relative utility of political activities to republicans compared to armed action.

The Sudan case study provides a contrasting example, and presents the most challenging test to the argument that social services can contribute to mediation and conflict transformation. Similar processes of change in the opportunity structures facing the Sudan People's Liberation Movement/Army (SPLM/A) during the second Sudanese civil war (1983-2005) are observable as in Northern Ireland, particularly with respect to the development of civil administration in SPLA held areas of South Sudan. From a conflict transformation perspective, however, the more important contribution that social services have made in South Sudan has been with respect to the development and maintenance of international linkages with the SPLA, principally through the operation of Operation Lifeline Sudan, an internationally brokered arrangement that allowed humanitarian relief to be provided in insurgent controlled regions of South Sudan during the war. This provided important international standing to the SPLA, especially in the period following the collapse of Ethiopian government support in 1991. The SPLA acted and was recognized as an important broker between the international humanitarian aid system and local populations on the ground. As a consequence, the presence of the SPLA as an actor on the international stage became normalized to the extent that sovereign governments and intergovernmental agencies maintained regular contacts with them, signed operational agreements with respect 
to humanitarian access and their representatives regularly paid visits to SPLA controlled areas of South Sudan. International recognition of the SPLA's involvement significantly reduced barriers to negotiation and enhanced engagement with the SPLA when it came to beginning an effective peace process. These positive results can be contrasted with the relative lack of international contact with the Lord's Resistance Army, a Ugandan insurgency that operated in much the same area over a similar timeframe.

The final case study considered was that of Tajikistan. Tajikistan represents an intermediate case with respect to the capacity of social service provision. Social services provided during the civil war were not as comprehensive nor as well funded as those in Northern Ireland, but were certainly of a higher capacity than services provided in South Sudan, if only because of inherited institutional endowments from the Soviet period. Tajikistan provides an interesting case study because the impact of social services can be observed in two quite distinct ways in different conflict-affected zones. In the remote Pamir region of Tajikistan, the Aga Khan foundation took a leading role in providing food and other support to the mainly Ismaili population there (with support from international donors), to such an extent that up to $90 \%$ of the food needs of the region were being met through international assistance during particular periods of conflict. The provision of these services and the related role of the Aga Khan Foundation as an honest broker with central government officials in the capital Dushanbe contributed to dampening down conflict in the Pamir region of the country, facilitating what represented a de facto separate peace between the population of the Pamir mountains and the central government.

The configuration of social services in southern Tajikistan and in Tajik refugee camps in northern Afghanistan influenced the peace process in a different manner, by contributing to the military weakness of the armed factions of the United Tajik Opposition (UTO) movement based in these locations. UTO controlled refugee camps in northern Afghanistan were relatively under- served with respect to social services compared to a nearby non-UTO controlled refugee camp. Refugees who had fled Tajikistan in late 1992 because of violence but did not wish to remain in Afghanistan over the long term could move to a non-UTO controlled camp. The repatriation program put in place by UNHCR also moved very quickly, initially without the agreement of the UTO. Repatriation activities were possible only because the UNHCR camp was not UTO controlled. There is also some evidence to suggest that the phased reduction of assistance in this camp together with the provision of reconstruction assistance in waraffected areas of southern Tajikistan (which was provided before a peace agreement was finally signed in 1997) may have also contributed to the quick return of refugees. The net effect of this configuration of social services was to slowly pull the rug out from underneath the UTO in northern Afghanistan. Without captive populations or the capacity to consistently insert and maintain itself as a broker between the international aid system and refugee populations, the armed UTO faction in northern Afghanistan was a relatively weaker organization - one more reliant on the patronage of local warlords than it might otherwise have been and one less well positioned to take political advantage of opportunities that arose in the wake of the peace agreement that ended the war in 1997. 
The dynamics described above do not necessarily apply to all situations. My research also argues that there are important limitations to or conditions when these kinds of changes are most likely to occur. Firstly, services provided in areas with an insurgent presence should be relatively autonomous from both the insurgents themselves and any other combatants, (including government forces) in order to provide the right kind of incentives for the development of political or civilian wings within insurgent movements. Services, under these circumstances, are neither part of the government's counter insurgency strategy (as was the case with international interventions in Afghanistan and Iraq), nor are they provided directly by the insurgents (as is the case in Lebanon with Hezbollah provided services, or Hamas provided services in Gaza). Secondly, insurgents themselves must be relatively dependent on the co-operation and goodwill of local populations. This typically arises when insurgents rely heavily on local populations for support of some kind - either for volunteers to fight, or for food, shelter or just silence. If insurgents garner most of their resources from the direct exploitation of natural resources - say diamonds, or hard woods, or if they are heavily financed by an external patron, they are less likely to be interested in the gains to be made from social services. It also helps if there is a history of services being provided in these areas before conflict begins; this places increased pressure of insurgents to allow such services to continue.

Despite the time it takes for these changes to take effect, these research findings offer the hope that our choices are not limited to only either minimizing the negative effects of aid and other social services during civil wars, or not providing aid at all. Instead, service providers, including aid organizations, may be able to offer support that can make political settlements more attainable over the long term. 


\section{References}

Anderson, M. (1998), "'YYou Save My Life Today, But for What Tomorrow?", Some Moral Dilemmas of Humanitarian Aid." In Hard Choices, Moral Dilemmas in Humantarian Intervention, ed. J. Moore. Lanham, MD: Rowman \& Littlefield Publishers.

(1999) Do No Harm - How aid can support peace - or war. 1st ed. Boulder, Colorado: Lynne Rienner Publishers.

Autesserre, S. (2006) "Local Violence, National Peace? Postwar "Settlement" in the Eastern D.R. Congo."

African Studies Review 49 (3):1-30.

Bayart, J. (1993) The State in Africa: The Politics of the Belly. London and New York: Longman.

Boal, F. W.(1981) "Ethnic Residential Segregation, Ethnic Mixing and Resource Conflict: A Study in Belfast, Northern Ireland." In Ethnic Segregation in Cities, ed. C. Peach, V. Robinson and S. Smith. Athens, Georgia: University of Georgia Press.

Boal, F., (2000) "Putting it all together." In Ethnicity and Housing, Accomodating Differences, ed. F. W. Boal. Aldershot, UK: Ashgate.

Buhaug, H., Cederman, L., Gleditsch, K.,( 2014) "Square Pegs in Round Holes: Inequalities, Grievances, and Civil War." International Studies Quarterly 58 (2):418-31.

Cederman, L.E., Glrditsch, K., Buhaug, H., (2013) Inequality, Grievances, and Civil War. Edited by M. Beissinger, J. A. Goldstone, M. Hanagan, D. McAdam, S. A. Soule, S. Staggenborg, S. Tarrow, C. Tilly, E.

J. Wood and D. Yashar. New York: Cambridge University Press.

Chapman, T. (1998) "The Same But Different: Probation Practice in Northern Ireland." In Social Work and Social Change in Northern Ireland, ed. M. Anderson, S. Bogues, J. Campbell, H. Douglas and M. McColgan. Belfast, UK: Central Council for Education and Training in Social Work.

Collier, P. (1999) "Doing well out of war." In Conference on Economic Agendas in Civil Wars. London.

Darby, J. \& Williamson, A., eds. 1978. Violence and the Social Services in Northern Ireland. London: Heinemann Educational Books Ltd.

Davies, J. (1969) "The J-Curve of Rising and Declining Satisfactions as a Cause of Some Great Revolutions and a Contained Rebellion." In The History of Violence in America, ed. H. D. Graham and T. R. Gurr. New York: Frederick A. Praeger.

Davies, V. (2002) "What Explains African Civil Wars: Politics or Economics?" In Politics and Economics of Africa, ed. F. Columbus. Huntington, New York: Nova Science Publishers, Inc.

De Mars, W. (2000) "War and Mercy in Africa." World Policy Journal 17 (2): 1-10.

De Waal, A. (1988) "Refugees and the Creation of Famine: The Case of Dar Masalit, Sudan." Journal of Refugee Studies 1 (2):127-40.

(1997) Famine Crimes : Politics and the Disaster Relief Industry in Africa. London \& Oxford, UK and Bloomington, Indiana: African Rights \& the International African Institute in association with James Currey \& Indiana University Press. 
Doherty, P. \& Poole M. (2000) "Living apart in Belfast: residential segregation in a context of ethnic conflict." In Ethnicity and Housing, Accomodating Differences, ed. F. W. Boal. Aldershot, UK: Ashgate.

Donnelly, C., Osborne, B., McKeown P., (2006) "Introduction: pluralism, devolution and education in Northern Ireland." In Devolution and pluralism in education in Northern Ireland, ed. C. Donnelly, B. Osborne and P. McKeown. Manchester, UK: Manchester University Press.

Fitzduff, M. (1995) "Managing community relations and conflict: voluntary organizations and government and the search for peace." In Voluntary Action and Social Policy in Northern Ireland, ed. N. Acheson and A. Williamson. Aldershot, UK: Avebury.

Galtung, J. (1964) "An Editorial." Journal of Peace Research 1 (1): 1-4. Gurr, R. (1970), Why Men Rebel. New Jersey: Princeton University Press.

Gurr, T. Ruttenbuerg, C. (1967) Research Monograph No. 28. The Conditions of Civil Violence: First tests of a causal model. New Jersey: Woodrow Wilson School of Public and International Affairs, Princeton University.

Hillyard, P. (1978) "Police and Penal Services." In Violence and the Social Services in Northern Ireland, ed. J. Darby and A. Williamson. London: Heinemann Educational Books Ltd.

Humphreys, M. (2005) "Natural Resources, Conflict and Conflict Resolution." Journal of Conflict Resolution 49 (4): 508-37.

Kalyvas, S. (2006) Violence in Civil War. Edited by M. Levi. New York: Cambridge University Press.

Keen, D. (1994) The Benefits of Famine, A political economy of famine and relief in southwestern Sudan 1983 - 1989. New Jersey: Princeton University Press.

_ (1999) "Making Famine in Sudan." Field Exchange, February 1999, 6 - 7.

Kennedy, S. \& Birrell, D. (1978) "Housing." In Violence and the Social Services in Northern Ireland, ed. J.

Darby and A. Williamson. London: Heinemann Educational Books Ltd.

Kevlihan, R. (2013), Aid, Insurgencies and Conflict Transformation: When Greed is Good. Edited by F. O. Hampson, C. Crocker and P. Aal. London: Routledge.

Kuperman, A. (2008) "The Moral Hazard of Humanitarian Intervention: Lessons from the Balkans."

International Studies Quarterly 52 (1): 49-80.

Lyons, H. (1978) "Health Services." In Violence and the Social Services in Northern Ireland, ed. J. Darby and A. Williamson. London: Heinemann Educational Books Ltd.

MacFarlane, N. (2006) "Book Review: Dangerous Sanctuaries: Refugee Camps, Civil War, and the Dilemmas of Humanitarian Aid. By Sara Kenyon." Perspectives on Politics 4 (1): 231-2.

Metelits, C. (2010) Inside Insurgency, Violence, Civilians and Revolutionary Group Behaviour. New York: New York University Press.

Middleton, N. \& O'Keefe. P.( 2006) "Politics, History and Problems of Humanitarian Assistance in Sudan."

Review of African Political Economy 33 (109): 543-59.

Murtagh, B.(2002) The Politics of Territory, Policy and Segregation in Northern Ireland. Edited by S. Dunn and V. Morgan. New York: Palgrave. 
O'Connor, F. (2002) A Shared Childhood, The story of the integrated schools in Northern Ireland. Belfast: The Blackstaff Press and Integrated Education Fund.

O'Hagan, L. (1999) "Life, Death and Aid: Humanitarian Organisations and International Politics." Irish Studies in International Affairs 10: 31-42.

Prendergast, J. (1996) Frontline Diplomacy: bumanitarian aid and conflict in Africa. Boulder, Colorado: Lynne Rienner Publishers.

Reno, W. (1998) Warlord Politics and African States. Boulder, CO: Lynne Rienner.

Sambanis, N. (2005) "Conclusion, Using Case Studies to Refine and Expand the Theory of Civil War." In Understanding Civil War, Evidence and Analysis, ed. P. Collier and N. Sambanis. Washington, D.C.: The World Bank.

Shirlow, P. (2000) "Fear, Mobility and Living in the Ardoyne / Upper Ardoyne Communities." Belfast: Mapping the Spaces of Fear Team, University of Ulster.

- (2001) "Fear and Ethnic Division." Peace Review 13 (1): 67-74.

(2003) "'Who Fears to Speak': Fear, Mobility, and Ethno-sectarianism in the Two 'Ardoynes'." The Global Journal of Ethnopolitics 3 (1): 76-91.

Shirlow, P. \& Murtagh, B.(2006) Belfast, Segregation,Violence and the City. Edited by P. Shirlow. London: Pluto Press.

Sislin, J., \& Pearson F. (2006) "Arms and Escalation in Ethnic Conflicts: The case of Sri Lanka."International Studies Perspectives 7 (2): 137-58.

Smyth, M., Morrisey, M., \& Hamilton, J. (2001) "Caring Through the Troubles: Health and Social Services in North and West Belfast." Belfast: The Institute for Conflict Research.

Stephen, F. (2005) ''A delicate matter': The politics of integrating education in Northern Ireland, 19651990." Queen's University, Belfast.

Tarrow, S.(2007) "Comparative Politics and Sociology: Love Lost and Regained." APSA-CP, Winter, 1-7.

Terry, F. (2002) Condemned to Repeat? The Paradox of Humanitarian Action. Ithaca, NY: Cornell University Press.

Thyne, C. (2006) "ABC's, 123's, and the Golden Rule: The Pacifying Effect of Education on Civil War, 1980-1999." International Studies Quarterly 50 (4): 733-54.

Urdal, H.( 2006) "A Clash of Generations? Youth Bulges and Political Violence." International Studies Quarterly 50 (3): 607-29.

von Tangen P. (1998) Prisons, Peace and Terrorism, Penal Policy in the Reduction of Political Violence in Northern Ireland, Italy and the Spanish Basque Country, 1968-97. New York: St. Martin's Press.

Wardlow, M. (2006) "The Northern Ireland Council for Integrated Education: moving beyond sectarianism: the drive for integrated schools." In Devolution and Pluralism in Education in Northern Ireland, ed. C. Donnelly, B. Osborne and P. McKeown. Manchester, UK: Manchester University Press.

Weinstein, J. (2007) Inside Rebellion, The Politics of Insurgent Violence. New York: Cambridge University Press. 
Rob Kevlihan is Executive Director of the Kimmage Development Studies Centre, and that capacity is also head of the International Development programme at Maynooth University (under a bilateral arrangement between both institutions). Rob has spent more than 15 years overseas prior to returning to Ireland to take up his post with Kimmage DSC. During that time, he has worked as a practitioner and scholar in the fields of development, humanitarian action, conflict prevention and international relations. He has extensive experience working in both Africa (including Sudan, Angola, Ghana and the Sahel region of West Africa) and Asia (both Central and South East Asia). Rob has an MA in International Relations from DCU and a Ph.D in IR from The American University, Washington, D.C. He also a fellow of Chartered Accountants Ireland.

Rob's research examines the nexus of conflict, development and security, with a particular focus on state building, conflict management and complex humanitarian emergencies. He has published single and coauthored peer reviewed articles in a number of scholarly journals, including International Studies Quarterly, Nationalities Papers, Disasters, Nations and Nationalism, Ethnopolitics, The European Journal of Development Research, African Security Review, Studies in Transition States and Societies and Irish Studies in International Affairs. He published his first book, entitled "Aid, Insurgencies and Conflict Transformation, When Greed is Good' in 2013. 